\title{
The Relationship BeTWEen MARKeTING INTELLIGENCE AND STRATEgic MARKeting
}

\author{
Peet Venter and Mari Jansen van Rensburg
}

UNISA Graduate School of Business Leadership

Accepted: February 2014

\begin{abstract}
Despite the importance attached to $\mathrm{MI}$ and other marketing information functions, surprisingly few studies have explicitly examined the relationship between $\mathrm{Ml}$ and strategic marketing decision-making. This article reports on a study conducted with the aim of determining the relationship between marketing intelligence (MI) and strategic marketing in South African organisations. A quantitative survey was conducted among 166 South African marketing decision-makers. The findings suggest a substantial gap between the importance and availability of key types of MI. Marketing decision-makers found the traditional MI and marketing tools of great value in supporting marketing decision-making, but the value of several of the newer $\mathrm{MI}$ tools and technologies was less clear. An analysis of MI practices suggested that MI quality and particularly information and communication technology (ICT) support for $\mathrm{MI}$ are areas requiring further attention.
\end{abstract}

Key words: marketing intelligence, strategic marketing, marketing decision-makers

JEL: M100

1

\section{Introduction}

The marketing concept states that organisations will be successful if they consistently address the needs of their customers better than their competitors (Walker, Mullins \& Larréché, 2008). Many organisations accordingly expend a great many resources on efforts to better understand their customers' needs and the nature of the markets they serve.

Given this dependence on external information, it is not surprising that the marketing function has played a leading role over many years in shaping the organisational processes for providing decision-makers with decisionsupport information. Marketing research originated as early as the 1930s (Taylor, 1936), followed by marketing intelligence (MI) (Kelley, 1965) and marketing information systems (MkIS) (Brien \& Stafford, 1969). The importance of information that supports marketing decisions has seemingly endured, with the Marketing Science Institute (2010) suggesting that, in its view, the most important research priority in marketing is "using market information to identify opportunities for profitable growth".
While marketing research, MI and MkIS have all enjoyed some measure of research attention over the years, their relationship with marketing decision-making has been notably absent from leading journals. In particular, the relationship between marketing information and strategic marketing decision-making is an aspect that has not been adequately studied. The literature review undertaken as part of the research reported here uncovered only two such studies. Lackman, Saban and Lanasa (2000) conducted descriptive research on the relationship between MI and strategic marketing. However, this study did not address the relative complexity of MI, and focused on it as one broad concept instead of a complex and interrelating set of subsystems and activities. Another study of interest was conducted by Wee (2001). This latter study considered how large companies in Asia use MI as input into their strategic management system and decision-making. The focus of Wee's study was specifically on the use of the web for MI purposes and the use of web-generated MI in strategic planning. Both studies confirmed the important contribution of MI to strategic marketing, suggesting that further research on 
the nature of the relationship between MI and strategic marketing could be beneficial to understanding how MI could better serve strategic marketing decision-makers.

The need for strategic MI systems has seemingly never been doubted, and over many years several authors have contributed to the discussion. Guidelines on how MI systems should be developed have been formulated (Goretsky, 1983), and possible designs for such systems have been proposed (King \& Cleland, 1974; Rothschild, 1979; Montgomery \& Weinberg, 1998; Mockler, 1992; Trim, 2004). Other authors have suggested that information specialists could participate more in the strategic decision-making process and have outlined conceptual processes for doing so (Trim \& Lee, 2008). Yet, despite the importance attached to MI and other marketing information functions, surprisingly few studies have explicitly examined the relationship between MI and strategic marketing decisionmaking, a gap in the extant literature this article addresses. In addition, a focus on marketing decision-makers in South Africa brings an African perspective to a field dominated by perspectives from other regions. The purpose of the research on which this article is based was thus to explore the relationship between marketing information and strategic marketing from the perspective of South African marketing decision-makers.

In the following sections, the theoretical background to MI and strategic marketing are explored. This is followed by a review of the chosen research methodology and the research findings and conclusions.

2

\section{Marketing intelligence: an overview}

For purposes of this article the definition of MI by Tan and Ahmed (1999:298) was used, namely that MI is "a continuing and interacting structure of people, equipment and procedures that, in combination, gather, sort, analyse and distribute pertinent, timely and accurate information for use by marketing decisionmakers to improve their marketing planning, implementation and control". Wee (2001) cautions that MI differs from market research, as the emphasis of MI is on the regular and systematic collection of data. On the other hand, typical market research projects examine specific problems, and are non-routine in nature. A framework depicting the MI process was subsequently developed to reflect the theoretical foundation of this study (see Figure 1). This framework emphasises the important role of information technology (IT) in the MI process.

\section{Data collection}

The first step in the MI process entails the gathering of internal and external data. A continuous flow of useful information is the lifeblood of a good MI system, including information about new technologies, markets, customers, the economy, the regulatory environment and so on (Wee, 2001). Huster (2005) suggests that firms need information about those internal and external environments associated with customers, competitors, markets and industry.

External data, according to Venter and Tustin (2009), is typically obtained by processes that generate mostly unstructured information about macro-environmental forces, competitors and customers from primary and secondary sources. Primary sources of information about the external environment include customers, manufacturers, dealers, distributors, research, the sales force and other staff members, physical evidence, trade associations, exhibitions, conferences and journalists (Venter \& Tustin, 2009; Wee, 2001). Secondary sources include sources of information in the public domain, including annual reports, government publications and information posted on the internet. The internet, according to Wee (2001), has the greatest potential for sourcing secondary sources of information. This potential is situated in the massive volume and easy availability of databases and information. Internal data, on the other hand, can also produce a wealth of knowledge and is found in company databases, file servers and on employees' desktops (Wee, 2001). Examples of source systems include legacy systems, enterprise resource planning systems, customer relationship management systems, online transaction processing and online clickstream data (Venter \& Tustin, 2009). 


\section{Figure 1}

A theoretical framework of the MI Process

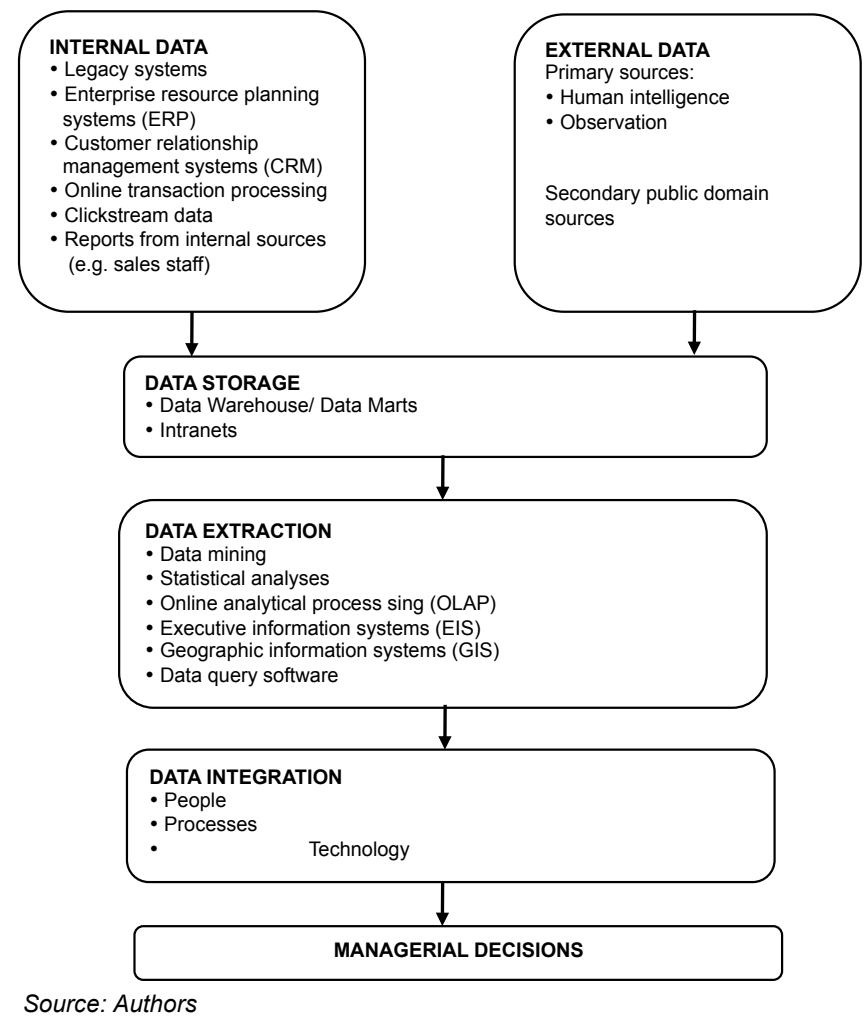

\section{Data storage}

The second step in the process is to store data and information obtained internally and externally in a format from which it can be easily extracted. Supporting technology to store data includes intranets, data warehouses or data marts (Venter \& Tustin, 2009).

\section{Data extraction}

In order to extract data, the third step entails various management information and analysis tools. Online analytical processing, data mining, executive information systems, geographical information systems and data query software can be used (Louw \& Venter, 2010; Venter \& Tustin, 2009; Wee, 2001).

\section{Data integration}

Although some companies generate considerable MI and invest significantly in supporting technology, the success of MI initiatives is ultimately determined by the dissemination and integration of intelligence to support decision-making. In the fourth step, data integration takes place. Data integration and access software are frequently cited as the greatest and most expensive challenge that organisations face (Bernstein \& Haas, 2008). There is a wide range of technological tools to support marketing decision-making (see, for example, Daniel, Wilson \& McDonald (2003) for a comprehensive review of IT tools and their use in marketing). However, Louw and Venter (2010) caution that technology alone is not always sufficient to support strategic decision-making, and that meaningful integration for purposes of strategic decision-making requires a combination of people, processes and technology. Scenario planning is an example of a process that could use people (for example, scenario planning teams, consultants and participating managers) and technology (for example, simulation technology) to integrate MI from various disparate sources into shared meaning and a basis for strategic decisionmaking. 


\section{Managerial decision-making}

The final step of the MI process refers to managerial decisions is based on MI. It is important to ensure the perception among marketing decision-makers that the quality of MI is acceptable.

3

\section{Marketing intelligence quality}

While the previous section considered the content and tools (processes and technologies) associated with MI, it does not address the important issue of MI quality. Conradie and Kruger (2006) suggest that there is a distinction between the inherent quality of the data, such as accuracy and reliability, and its pragmatic quality, such as timeliness and format. These make it more useful to end-users.

In this article the relationship between marketing intelligence and strategic marketing is of particular interest.

\section{4}

\section{Marketing intelligence and strategic marketing}

While it is commonly accepted that MI is beneficial to the organisation, it is not absolutely clear how it contributes to improved strategic decision-making and organisational performance. In this article, we examine the relationship of MI with strategic marketing as one of the possibilities for contributing to improved strategic decision-making.

Strategic marketing is commonly accepted to be the process of defining the market clearly (Forlani \& Parthasarathy, 2003), segmenting the market, targeting attractive market segments, and positioning the organisation in the targeted segments (cf. Cravens \& Piercy, 2006; Sarvary \& Elberse, 2006; Best, 2009; Venter \& Jansen van Rensburg, 2009; Dibb, Simkin, Pride \& Ferrell, 2012).

In most markets, the extent of customer requirements is too diverse to allow an organisation to satisfy all the needs of customers all of the time, and market segmentation is an effort to divide a market into several submarkets with relatively homogeneous requirements. Target market selection is the next logical step to follow segmentation. This process involves the evaluation of the relative attractiveness of market segments based on the opportunities they present to the organisation, and selecting one or more attractive segments to target (Sarvary \& Elberse, 2006). Strategically, segmentation and targeting allow organisations to position and tailor their offerings for one or a number of the identified segments based on market fit (Taghian \& Shaw, 2010; Tonks, 2009). Marketing objectives and strategies should thus be specific per target market, and information systems should be geared to provide marketing decision-makers with the required information per segment, as well as with MI to identify marketing opportunities (McDonald \& Dunbar, 2004; Taghian \& Shaw, 2010).

Despite the obvious dependence of strategic marketing decision-making on the availability of MI, little research has been done on how MI supports strategic marketing decision-making. Lackman, Saban and Lanasa (2000) examined the value of MI to tactical and strategic planning, and found it to be generally useful to planning processes in the organisation. Their research also indicated that customers, manufacturers and R \& D departments are the most important internal sources of information, while client meetings are by far the most important sources of external information. Wee (2001) examined the use of the internet in strategic planning and found it to be a useful tool in supplementing MI. A considerable body of research has considered the role of market orientation in organisational success. The marketing concept manifests in organisations as market orientation, which Shoham, Rose and Kropp (2005) describe as the firm's ability to anticipate, react to and capitalise on environmental changes, leading to superior performance. In practice, this could be described as the gathering, dissemination and use of information in decision-making (Jaworski \& Kohli, 1993). Market orientation has been linked positively to superior organisational performance in several studies (for example, Aldas-Manzano, Küster \& Vila, 2005; Kara, Spillan \& DeShields, 2005). Market orientation has also been linked positively to various aspects of marketing, such as marketing capabilities (Morgan, Vorhies \& Mason, 2009) and marketing practice (Ellis, 2005), but its 
relationship with strategic marketing has also not been comprehensively explored in the extant research. This ostensible gap in the literature led to the framing of the research questions for this study, as outlined in the next section.

\section{5}

\section{Research questions}

The literature uncovered four broad constructs that will be investigated in the context of this study. In the first instance, the content of MI is important, and the availability of various types of internal and external MI can have an effect on its perceived efficacy. Secondly, the tools (the technology and processes) of MI can also play a role in the support that MI offers to strategic marketing in the organisation. Thirdly, the perceived quality of MI is an important consideration. The fourth construct, and also the dependent variable in the context of the study, is strategic marketing.

Since extant research has only indirectly or partly examined the relationship between MI and strategic marketing decision-making, this study will investigate in more detail how MI contributes to strategic marketing insight and decision-making. In this regard, three specific research questions are addressed in this article:

- What is the relationship between the availability of MI and strategic marketing?

- What is the relationship between the use of MI-related tools and technologies and strategic marketing?

- What is the relationship between MI quality and strategic marketing?

A survey among marketing decision-makers formed the basis of our exploration of these questions.

\section{6}

\section{Research methodology}

As the purpose of the research was to determine the relationship between $\mathrm{MI}$ and strategic marketing, a quantitative survey was selected as the research method. The research targeted marketing decision-makers in formal South African business organisations with more than 100 employees and more than R500 000 per annum in marketing advertising expenditure, as these organisations were most likely to have formalised MI and strategic marketing processes and systems.

In the absence of a universally recognised and representative sampling frame of South African marketing decision-makers, a variety of sources (e.g. electronic databases obtained from industry associations and marketing publications like The Red Book) were used to compile a sampling frame of about 700 potential respondents across South Africa. The survey targeted one key marketing decisionmaker in each organisation, so that each usable response represented a unique organisation and an individual involved in strategic marketing.

In order to elicit a higher response rate, structured telephone interviews were conducted with the selected respondents using a survey approach. This process allowed interviewers to confirm the participants' suitability as key decision-makers with the required credentials. Data were collected by means of computerassisted telephone interviewing (CATI) using questionnaires with a predetermined set of questions. Respondents were also given the choice to complete the survey online in their own time. This method reduced costs, increased timeliness and improved data quality (Couper, 2005:487). The interviews were conducted by a research fieldwork company familiar with the sample frame, and the average interview lasted between 10 and 15 minutes. Quota sampling was used owing to budgetary constraints. The research company was instructed to obtain at least 50 responses in each of the three broad sectors, namely manufacturing, trade (wholesale and retail) and service. The quota set was in line with the requirements for further statistical analysis and allowed for comparison across industries. In total, 167 usable responses were obtained.

The questionnaire was subjected to a pilottesting phase, during which it was completed by a group of four MI experts. In addition, four senior marketing academics and a statistician reviewed the questionnaire, particularly the representativeness and suitability of the questions from the perspective of content and data. All the scales used a five-point Likert scale as measurement. The MI section of the questionnaire was adapted from Venter and Tustin (2009) and contained the following sections: 
- A section measuring the perceived importance and availability of 13 categories of information, as well as the overall perceived quality of MI;

- A MI scale with 13 items covering MI quality (8 items) and the relationship between ICT and MI (5 items);

- A section measuring the usage of $18 \mathrm{MI}$ tools and technologies, whether the tools and technologies were managed by the marketing function, and the perceived value of these tools and technologies to the marketing decision-making process. This scale was designed using processes and technologies as defined by the MI process described in Figure 1, and commonly used by marketing decision-makers.

The strategic marketing scale consisting of 10 items was developed, with reference to McDonald and Dunbar (2004).

The data was analysed using IBM SPSS software. Data analysis included descriptive measures (such as frequency analysis and cross-tabulations), but to explore the dimensionality of data and the relationships between constructs, exploratory factor analysis and correlation analysis were used. Factor analysis was used to identify representative variables. Varimax rotation was employed to derive a simpler factor structure, and factors with Eigenvalues less than 1 were screened out (Hair, Black, Babin, Anderson \& Tatham, 2005:90). To confirm the suitability of variables in the correlation matrix and the significance of correlations, the Kaiser-MeyerOlkin (KMO) measure of sampling adequacy and Bartlett's test of sphericity were calculated. In line with norms according with factor structures used in social sciences, items with a communality of higher than 0.80 or less than 0.40 were removed from the data; minimum factor loadings of 0.32 were considered and cross-loading items were dropped from the analysis if there were several adequate to strong loaders (factor loading of 0.50 or higher) on each factor (Velicer \& Fava, 1998). Cronbach's alpha values were used as a measure of internal reliability for the identified factors. Factors with Cronbach's alpha coefficients that exceeded the suggested lower limit of 0.50 for the social sciences (Kent, 2001) were retained. Finally, correlation analyses, considering Spearman's rank correlation coefficients (Spearman's Rho or $r_{s}$ ), were carried out to assess the strengths of relationships between the identified factors and strategic marketing, and to calculate the level of significance of these relationships. The resulting $r_{s}$ coefficients were assessed according to their effect size, using the guidelines of 0.1 to 0.23 as a small effect size, 0.24 to 0.36 as a medium effect size, and 0.37 or larger as a large effect size (Cohen, 1988).

In the section below the results of these analyses are discussed.

\section{7}

\section{Results}

In the sections that follow, the research questions are addressed by examining the respondent profiles, the strategic marketing construct, the relationship between the availability of MI and strategic marketing, the relationship between MI tools and technologies and strategic marketing and the relationship between MI quality and strategic marketing.

\subsection{Respondent profiles}

The survey yielded 166 usable responses. Respondents were concentrated in the economically dominant Gauteng province (74 per cent of respondents), and represented a range of industries (see Table 1), the primary sector being the most strongly represented. Respondents were mostly at the level of senior management (48 per cent) or middle management (43 per cent), with the remainder ( 9 per cent ) at director level.

\subsection{The strategic marketing scale and index}

This question (the strategic marketing scale) comprised a list of items measuring the perceptions of respondents regarding strategic marketing in their organisations. . Figure 2 is a summary of the scale items and the top box scores for each of the items ("strongly agree"). Figure 2 suggests that most respondents agree that their organisations are defining markets and segments, and targeting specific segments. There was, however, less agreement about their organisations' execution and monitoring of segment-based strategies. In particular, respondents are not very confident that their 
information systems are supporting marketing decision-makers with the required information on market segments, or that they have formal processes for identifying market opportunities.

The overall strategic marketing scale has a Cronbach's alpha coefficient of 0.85 , suggesting a relatively high level of reliability. To facilitate easier analysis, the strategic marketing scale was combined into one strategic marketing index measurement, comprising the mean for all 10 scale items. The calculation of the index provided a basis for determining the relationship between MI requirements and availability.

Figure 2

The strategic marketing scale

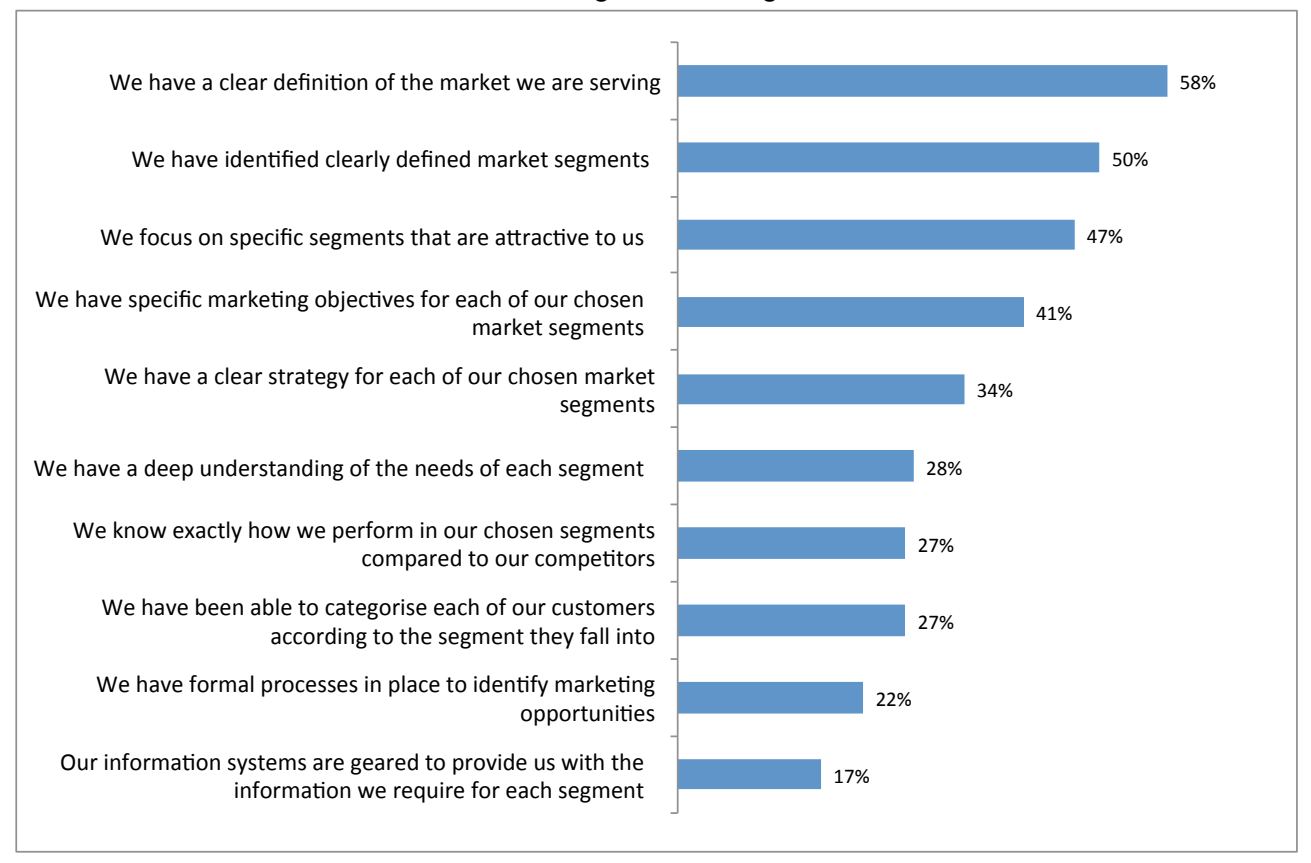

\subsection{MI requirements and availability}

The questionnaire examined the relative importance and availability of 13 types of MI. In order to simplify this analysis, exploratory factor analysis was used to examine the underlying dimensionality of the "availability" scale. No individual item had a negative effect on the acceptable Cronbach's alpha coefficient of 0.75 , and the KMO measure of sampling adequacy of 0.79 and the highly significant outcome of Bartlett's test of sphericity (significance of 0.00) indicated the scale's suitability for factor analysis. Two items (availability of "operational performance data" and "customer demographics") were removed owing to high inter-item communalities and excluded from further analysis. Varimax rotation was employed to derive a simpler, clearer structure. The factor analysis yielded four factors, explaining about 66 per cent of variance in the scale.

The results of the rotated component matrix are depicted in Table 2. All factors exceeding the Cronbach's alpha coefficient cut-off point of 0.50 were included in further analysis. Although two factors, namely "Political and regulatory intelligence" and "Business intelligence", had only two items each. These factors were retained owing to the relatively high factor loadings of their items and the reliability of the scale, which exceeded the threshold. In order to examine the relationship with other variables, an index was created for each factor, consisting of the mean of means of the factor items. This section of the questionnaire also contained a question on the overall perception of the quality of MI, which was included in the correlation analysis. 
Table 2

Availability of MI rotated component matrix

\begin{tabular}{|l|c|}
\hline Factors and items & Factor loadings \\
\hline Factor 1: Market intelligence $(\boldsymbol{\alpha}=\mathbf{0 . 7 5 0})$ & 0.615 \\
\hline Availability of direct customer feedback & 0.823 \\
\hline Availability of competitor intelligence & 0.611 \\
\hline Availability of sales forecasts & 0.661 \\
\hline Availability of information on potential business partners & 0.725 \\
\hline Factor 2: Political and regulatory intelligence $(\boldsymbol{\alpha}=\mathbf{0 . 5 7 2 )}$ & 0.761 \\
\hline Availability of information from regulatory bodies & 0.873 \\
\hline Availability of information on political trends & 0.771 \\
\hline Factor 3: Business intelligence ( $\alpha=\mathbf{0 . 6 9 4 )}$ & \\
\hline Availability of internal financial information & \\
\hline Availability of analysis of sales data & 0.885 \\
\hline Factor $4:$ Macro-environmental intelligence $(\boldsymbol{\alpha}=\mathbf{0 . 6 2 5})$ & 0.554 \\
\hline Availability of information on economic trends & 0.452 \\
\hline Availability of information on technological trends & \\
\hline Availability of information on social trends & \\
\hline
\end{tabular}

The four factors represented in Table 2 are briefly explained below:

- Market intelligence contains intelligence related to the market environment, including customers, competitors and suppliers.

- Political and regulatory intelligence refers to intelligence that focuses mainly on regulatory bodies and the political climate. Although these elements are generally regarded as part of the institutional environment in the macro environment, they were identified in this study as a separate factor.

- Business intelligence covers the elements related to structured internal data, mostly financial in nature.

- Macro-environmental intelligence includes those elements related to the macro environment, particularly the economic and technological environments.

The correlation of these four factors with "overall quality of MI" and the strategic marketing index is summarised in Table 3.

The results depicted in Table 3 suggest that the overall quality of MI has a relatively large effect on the strategic marketing index, while the other factors have either a small effect (MI, political and regulatory intelligence and business intelligence factors) or no significant effect (macro intelligence). However, all four factors, have a medium (macro intelligence, political and regulatory intelligence and business intelligence) to large (market intelligence) effect on the overall perceived quality of MI. These findings suggest that the perceived overall quality of MI has a moderating role between the types of MI and strategic marketing. On their own, the different categories of MI have a limited effect on strategic marketing, but in combination they have a much larger effect on the perceived quality of MI, which in turn has a large effect on the strategic marketing index. The findings also emphasise the relative importance of customer and competitor intelligence (market intelligence), which has the largest direct and indirect effects on the strategic marketing index.

Paradoxically, it is also customer and competitor information that displays the largest gap between the importance of the intelligence category and its availability, suggesting that, while this information may be the most important when it comes to strategic marketing, it is also the most difficult to obtain. The gap was calculated by comparing the frequencies for the top two boxes for the importance of the intelligence category ("very important" and "critical") to the top two boxes for its availability ("very good" and "excellent"). 
Table 3

Relationship between MI availability, MI quality and strategic marketing

\begin{tabular}{|c|c|c|c|c|c|c|c|}
\hline$N=166$ & & $\begin{array}{l}\text { Strategic } \\
\text { marketing } \\
\text { Index }\end{array}$ & $\begin{array}{c}\text { Factor 1: } \\
\text { Market } \\
\text { intelligence }\end{array}$ & $\begin{array}{l}\text { Factor 2: } \\
\text { Political and } \\
\text { regulatory } \\
\text { intelligence }\end{array}$ & $\begin{array}{c}\text { Factor 3: } \\
\text { Business } \\
\text { intelligence }\end{array}$ & $\begin{array}{c}\text { Factor 4: } \\
\text { Macro } \\
\text { intelligence }\end{array}$ & $\begin{array}{c}\text { Overall } \\
\text { quality of } \\
\text { marketing } \\
\text { intelligence }\end{array}$ \\
\hline \multirow{2}{*}{$\begin{array}{l}\text { Strategic marketing } \\
\text { index }\end{array}$} & $r_{\mathrm{s}}$ & 1.000 & & & & & \\
\hline & Sig. (2-tailed) & . & & & & & \\
\hline \multirow{2}{*}{$\begin{array}{l}\text { Factor 1: Market } \\
\text { intelligence }\end{array}$} & $\mathrm{r}_{\mathrm{s}}$ & $.239^{* *}$ & 1.000 & & & & \\
\hline & Sig. (2-tailed) & .002 & . & & & & \\
\hline \multirow{2}{*}{$\begin{array}{l}\text { Factor } 2 \text { : Political } \\
\text { and regulatory } \\
\text { intelligence }\end{array}$} & $r_{\mathrm{s}}$ & $.170^{\circ}$ & $.389^{m \prime}$ & 1.000 & & & \\
\hline & Sig. (2-tailed) & .029 & .000 & . & & & \\
\hline \multirow{2}{*}{$\begin{array}{l}\text { Factor 3: Business } \\
\text { intelligence }\end{array}$} & $r_{\mathrm{s}}$ & $.182^{*}$ & $.411^{n *}$ & $.274^{n *}$ & 1.000 & & \\
\hline & Sig. (2-tailed) & .019 & .000 & .000 & . & & \\
\hline \multirow{2}{*}{$\begin{array}{l}\text { Factor 4: Macro } \\
\text { intelligence }\end{array}$} & $r_{\mathrm{s}}$ & .109 & $.380^{\prime \prime}$ & $.419^{\prime \prime}$ & $.225^{\prime \prime}$ & 1.000 & \\
\hline & Sig. (2-tailed) & .161 & .000 & .000 & .004 & . & \\
\hline \multirow{2}{*}{$\begin{array}{l}\text { Overall quality of } \\
\text { marketing } \\
\text { intelligence }\end{array}$} & $r_{\mathrm{s}}$ & $.396^{\prime \prime}$ & $.467^{\prime \prime \prime}$ & $.322^{\prime \prime}$ & $.336^{\prime \prime}$ & $.323^{m \prime \prime}$ & 1.000 \\
\hline & Sig. (2-tailed) & .000 & .000 & .000 & .000 & .000 & . \\
\hline
\end{tabular}

"Correlation is significant at the 0.01 level

"Correlation is significant at the 0.05 level.

Table 4

MI importance and availability

\begin{tabular}{|c|c|c|c|}
\hline & $\begin{array}{l}\text { Importance \% } \\
\text { (Top } 2 \text { Box) }\end{array}$ & $\begin{array}{l}\text { Availability \% } \\
\text { (Top } 2 \text { Box) }\end{array}$ & $\begin{array}{c}\text { Gap (Importance } \\
\text { minus availability) \% }\end{array}$ \\
\hline Competitor intelligence & 84 & 37 & 47 \\
\hline Direct customer feedback & 85 & 47 & 38 \\
\hline Economic trends & 72 & 49 & 23 \\
\hline Technological trends & 63 & 42 & 21 \\
\hline Sales forecasts & 80 & 61 & 19 \\
\hline Social trends & 53 & 34 & 19 \\
\hline Information on potential business partners & 51 & 33 & 18 \\
\hline Information from regulatory bodies & 54 & 36 & 18 \\
\hline Analysis of sales data & 80 & 69 & 11 \\
\hline Internal financial information & 76 & 68 & 8 \\
\hline Political trends & 42 & 34 & 7 \\
\hline
\end{tabular}

The existence of such large gaps with regard to MI can perhaps be explained by the capabilities, effort and cost associated with targeted MI gathering. Comparatively, business intelligence such as internal financial information is produced as a standard operating procedure for the business, while macro intelligence such as economic or technological trends is often widely available as commercial reports or in the public domain.

The findings in this section support the notion that MI is generally valuable to the strategic marketing process and that by improving the availability and quality of MI, the strategic marketing effort can be improved. Of the different information categories, market intelligence has the largest direct and indirect effects on strategic marketing, and this area is accordingly an important focus area for organisations doing strategic marketing.

\subsection{Use of MI tools and technologies}

This question measured the use (see Table 5) and perceived value (see Figure 3) of MI tools and technologies in the organisation. The question measured whether the respondent's 
organisation formally used the information tools specified, and whether the functional responsibility for the tools resided within ("reported to") the marketing function. The results are summarised in Table 5.

Table 5

Use of MI tools and technologies

\begin{tabular}{|l|c|c|}
\hline \multicolumn{1}{|c|}{ Tools } & $\begin{array}{c}\text { Reporting to } \\
\text { marketing } \\
\text { organisations (\%) }\end{array}$ & $\begin{array}{c}\text { Usa of organisations } \\
\text { using it) }\end{array}$ \\
\hline Marketing Intelligence & 86 & 97 \\
\hline Customer relationship management (CRM) & 82 & 72 \\
\hline Market segmentation & 80 & 90 \\
\hline Marketing research surveys & 79 & 92 \\
\hline Intranet & 77 & 55 \\
\hline Competitive intelligence & 69 & 81 \\
\hline Data warehouse & 65 & 36 \\
\hline Executive information systems (EIS) & 64 & 44 \\
\hline Knowledge management & 58 & 57 \\
\hline Planning support software & 55 & 36 \\
\hline Data query software & 54 & 50 \\
\hline Scenario planning & 54 & 60 \\
\hline Geographical information systems (GIS) & 52 & 59 \\
\hline Data mining & 52 & 54 \\
\hline Online analytical processing (OLAP) & 49 & 70 \\
\hline Enterprise resource planning (ERP) & 48 & 32 \\
\hline
\end{tabular}

MI, market segmentation, CRM, competitive intelligence and marketing research feature prominently as the tools most widely used for marketing decision-making, and marketing also plays a key role as the organisational custodian of these tools. In fact, perhaps owing to the traditional external information focus of marketing, this function seemingly acts as the organisational custodian of many MI-related tools and technologies with an external focus on, for example, competitors and customers.

Respondents were also asked about the marketing decision-support value of each of the tools that they use (including their own internet searches). The results (top two boxes of "very valuable" and "extremely valuable") are summarised in Figure 3. It appears that marketing decision-makers attach high value to the tools they use the most and exert most control over, such as marketing intelligence, competitive intelligence, CRM, market segmentation and marketing research surveys. Outside of this primarily functional information, scenario planning, knowledge management, their own internet searches and Executive Information Systems (EIS) are seen as the most valuable tools by those who use them. Despite the purported analytical power of Geographic Information Systems (GIS), marketing decisionmakers do not appear to find it exceptionally valuable at this point, perhaps owing to the cost and complexity of implementing GIS for marketing decision-support purposes.

Despite the general support for the value of MI tools and technologies to marketing decision support, the number of tools used has only a medium effect on the strategic marketing index $\left(r_{s}=0.268, p \leq 0.000\right)$. The findings reported in this section support the notion that organisations use MI tools and technologies relatively widely, and marketing decisionmakers perceive such tools (especially those controlled by the marketing function) as useful in supporting marketing decision-making. However, the statistical evidence that the use of MI tools and technologies leads to better strategic marketing practice is not particularly convincing. 
Figure 3

The perceived decision support value of $\mathrm{MI}$ tools and technologies

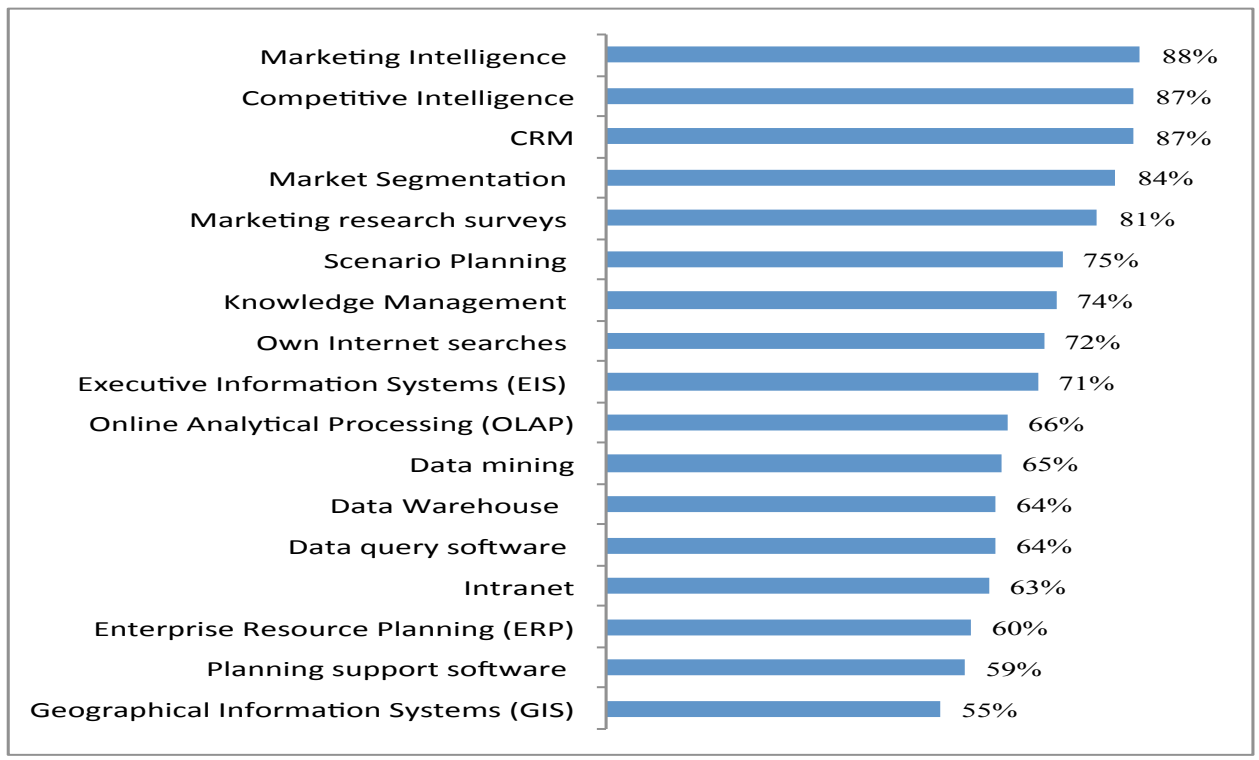

\subsection{The relationship between $\mathrm{MI}$ and strategic marketing}

The MI item scale consisted of 11 items, which were reduced to 10 items after the original reliability analysis. The remaining 10 items displayed a Cronbach's alpha of 0.83 , suggesting an acceptable level of reliability. In order to explore the underlying dimensionality of the MI scale, exploratory factor analysis was used. The KMO measure of sampling adequacy of 0.86 and the highly significant outcome of
Bartlett's test of sphericity (significance of 0.00) suggested that the scale is suitable for factor analysis. Varimax rotation was employed to derive a simpler, clearer structure. The factor analysis yielded two factors explaining 54 per cent of variance in the scale.

The result of the rotated component matrix is depicted in Table 6. Both factors exceeded the suggested Cronbach's alpha coefficient cut-off point of 0.50 and were included in further analysis.

Table 6

MI scale rotated component matrix

\begin{tabular}{|l|c|}
\hline Factors and items & Factor loadings \\
\hline Factor $\mathbf{1 :}$ MI effectiveness ( $\alpha=\mathbf{0 . 8 1 5}$ ) & 0.584 \\
\hline Marketing information I receive for decision-making is generally accurate. & 0.763 \\
\hline It is easy for me to obtain MI in the format I require. & 0.587 \\
\hline $\begin{array}{l}\text { As a user of MI my requirements are always taken into account when marketing information systems } \\
\text { are designed. }\end{array}$ & 0.570 \\
\hline In our organisation, the IT department really understand the information needs of marketing. & 0.681 \\
\hline Information is usually available to me by the time I need it. & 0.695 \\
\hline I routinely receive MI relevant to my responsibilities without asking for it. & 0.603 \\
\hline Our organisation uses MI to create a competitive edge in the industry. & .803 \\
\hline Factor 2: ICT support for MI ( $\alpha=\mathbf{0 . 7 3 7 )}$ & .860 \\
\hline Our marketing strategy influences our IT strategy. & .650 \\
\hline IT assists me in making better marketing decisions. & \\
\hline IT makes it easy to get access to the right intelligence. & \\
\hline
\end{tabular}


The two factors represented in Table 6 are explained above.

- MI effectiveness contains elements of pragmatic quality (format and timeliness of MI) and inherent quality (accuracy), but also contains elements that relate to the relationship between IT and marketing, and the ease of access to MI.

- ICT support for MI reflects the extent to which IT serves the marketing strategy, and the extent to which IT supports better marketing decision-making.
The relationship between these two factors and the strategic marketing index is indicated in Table 7. The findings suggest that the two factors have a large effect on each other, while only Factor 1 (MI quality) has a large effect on the strategic marketing index. Factor 2 (ICT support for MI) has a small effect on the strategic marketing index. This finding suggests that the MI quality construct may have a moderating role between ICT support for MI and strategic marketing.

Table 7

The relationship between $\mathrm{MI}$ factors and the strategic marketing index

\begin{tabular}{|l|l|c|c|c|}
\hline \multicolumn{2}{|l|}{$\mathrm{n}=166$} & $\begin{array}{c}\text { Strategic marketing } \\
\text { index }\end{array}$ & $\begin{array}{c}\text { Factor 1: } \\
\text { MI effectiveness }\end{array}$ & $\begin{array}{c}\text { Factor 2: } \\
\text { ICT support for MI }\end{array}$ \\
\hline \multirow{2}{*}{$\begin{array}{l}\text { Strategic marketing } \\
\text { index }\end{array}$} & $\mathrm{r}_{\mathrm{s}}$ & 1.000 & \\
\cline { 2 - 5 } & Sig. (2-tailed) &. & 1.000 & \\
\hline $\begin{array}{l}\text { Factor 1: } \\
\text { MI effectiveness }\end{array}$ & $\mathrm{r}_{\mathrm{s}}$ & $.357^{* *}$ &. & $.495^{* *}$ \\
\hline \multirow{2}{*}{$\begin{array}{l}\text { Factor 2: } \\
\text { ICT support for MI }\end{array}$} & Sig. (2-tailed) & .000 & .000 & 1.000 \\
\hline
\end{tabular}

This aspect was explored further by examining the relationship between the usage of MI tools and technologies and the MI factors, as well as the relationship with overall MI quality (see Table 8). Surprisingly, the use of MI tools and technologies has a large effect on MI quality, but a small effect on ICT support for MI. The MI effectiveness construct has a large effect on the perceived overall quality of $\mathrm{MI}\left(\mathrm{r}_{\mathrm{s}}=0.442\right.$, $\mathrm{p} \leq 0.000$ ), reinforcing the moderating role of MI quality.

Table 8

The relationship between the use of $\mathrm{MI}$ tools and $\mathrm{MI}$ factors

\begin{tabular}{|c|c|c|c|c|c|}
\hline \multicolumn{2}{|l|}{$n=166$} & $\begin{array}{c}\text { Overall quality } \\
\text { of MI }\end{array}$ & $\begin{array}{l}\text { Use of MI } \\
\text { tools }\end{array}$ & $\begin{array}{l}\text { Factor 1: MI } \\
\text { effectiveness }\end{array}$ & $\begin{array}{l}\text { Factor 2: ICT } \\
\text { support for MI }\end{array}$ \\
\hline \multirow{2}{*}{ Overall quality of MI } & $r_{s}$ & 1.000 & & & \\
\hline & Sig. (2-tailed) & . & & & \\
\hline \multirow{2}{*}{ Use of MI tools } & $r_{s}$ & $.287^{\kappa *}$ & 1.000 & & \\
\hline & Sig. (2-tailed) & .000 & . & & \\
\hline \multirow{2}{*}{ Factor 1: MI effectiveness } & $r_{s}$ & $.442^{\mathrm{x}}$ & $.398^{n *}$ & 1.000 & \\
\hline & Sig. (2-tailed) & .000 & .000 & . & \\
\hline \multirow{2}{*}{ Factor 2: ICT support for MI } & $r_{\mathrm{s}}$ & $.246^{\prime \prime}$ & $.200^{\prime \prime}$ & $.495^{\prime \prime}$ & 1.000 \\
\hline & Sig. (2-tailed) & .001 & .010 & .000 & . \\
\hline
\end{tabular}

Further analysis of the top two box scores ("agree" and "strongly agree") for the MI item scale (Figure 4) reveals that respondents were generally more positive about MI effectiveness than they were about ICT support for MI. Respondents were particularly positive about the accuracy of MI and the potential for creating competitive advantage with MI. However, the format that MI was presented in seemed problematic and respondents were not very positive about IT understanding the information needs of marketing. In fact, the results generally suggest that the relationship between MI and ICT is a potential problem area. 
Figure 4

A comparison of perceived scores on the MI scale

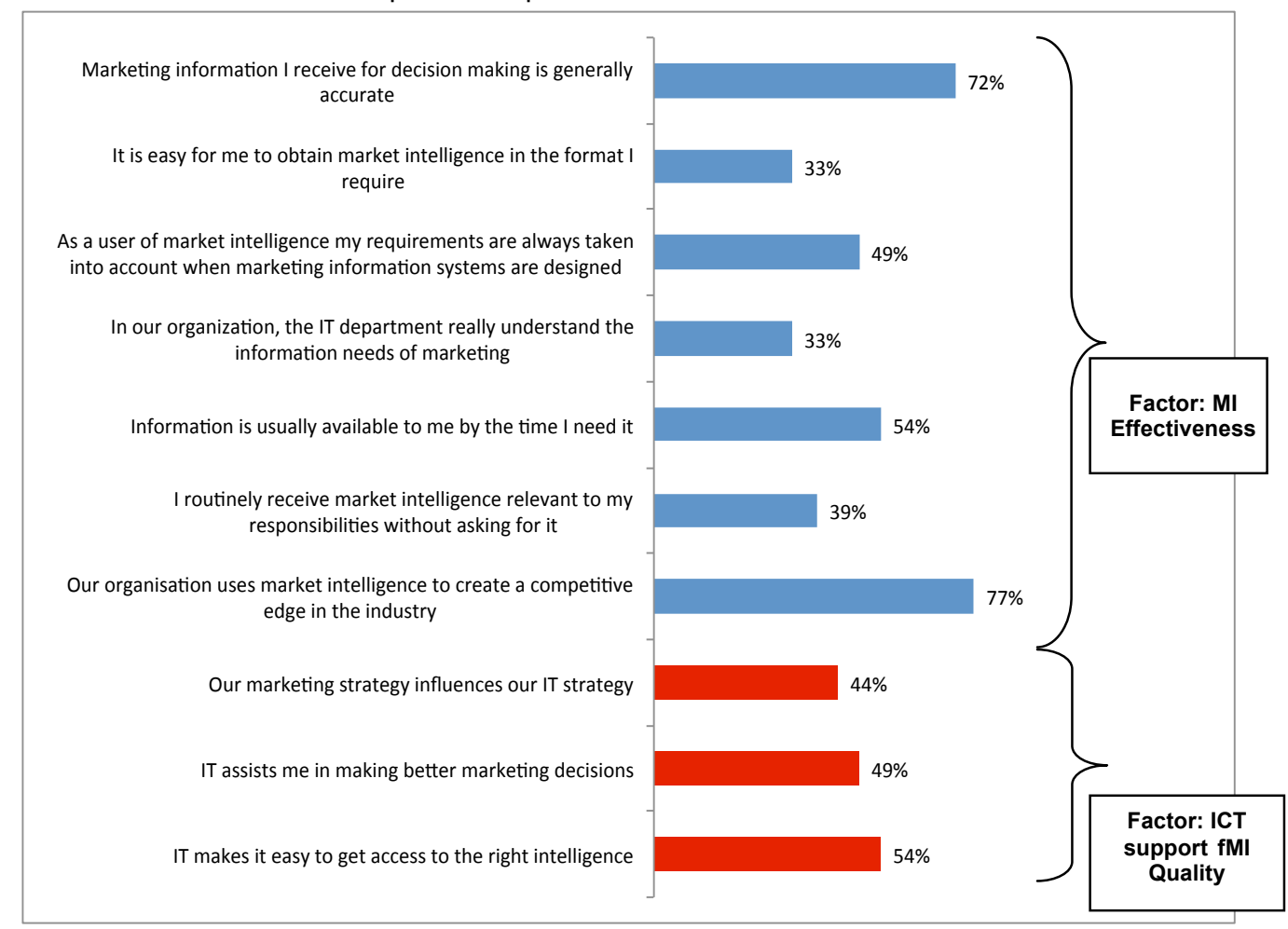

The next section concludes the article and contains recommendations to practitioners and academics.

\section{8}

\section{Conclusion}

The study set out to answer three research questions (1) What is the relationship between the availability of MI and strategic marketing? (2) What is the relationship between the use of MI-related tools and technologies and strategic marketing? and (3) What is the relationship between MI quality and strategic marketing?

The data suggested that the availability of various categories of MI has an indirect effect on strategic marketing, as depicted in Figure 5. While none of the categories of MI should be neglected, the findings suggest that the availability of market intelligence (intelligence on customers, competitors and suppliers) has the greatest direct effect on the perception of the overall quality of MI and perhaps plays a mediating role, given its strong relationships with other categories of MI. This category of MI is also where the greatest gap between importance and availability occurs, perhaps due to the complexity, effort and cost associated with obtaining primary market intelligence. It is accordingly recommended that organisations invest in improving their investment in the availability and quality of market intelligence.

When it comes to the MI tools (technologies and processes) used by marketing decisionmakers, it would seem that there is a relatively weak relationship between the number of tools and techniques used and strategic marketing, and only a moderately strong relationship with the ICT Support construct. However, there is a fairly strong positive relationship with the MI Effectiveness construct. This finding would seem to suggest that organisations invest carefully in tools and techniques with a view to creating value for marketing decision-makers, rather than just investing to broaden the portfolio of tools and techniques being used. It is further evident that the most valuable tools 
are those providing a deeper understanding of the market environment (e.g. market intelligence, competitor intelligence, CRM and market segmentation), which makes one wonder why the gap between the importance and availability of such types of MI is so wide, yet it is evidently not addressed by organisations.

Figure 5

A conceptual framework of the relationship between $\mathrm{MI}$ availability and strategic marketing

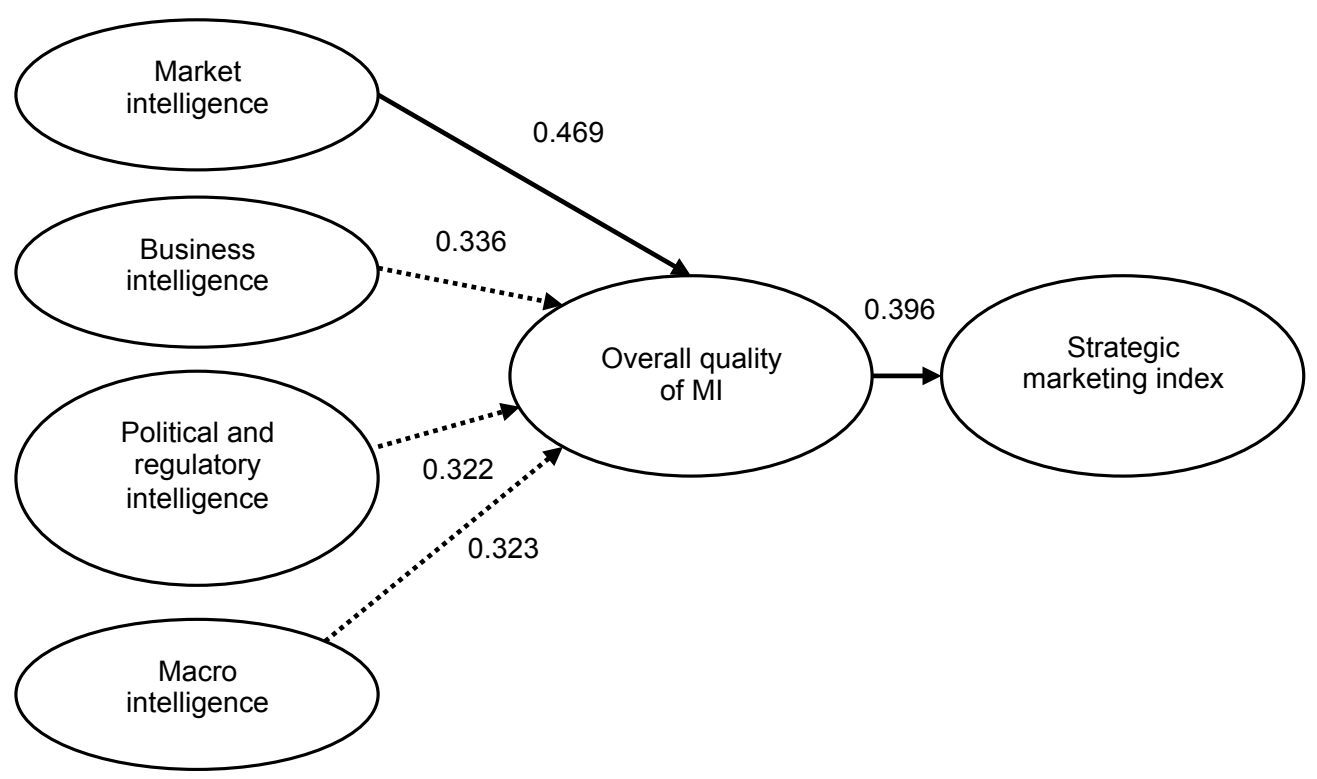

Figure 6 depicts a conceptual framework to illustrate the relationship between the MI which was the focus of the third research effectiveness construct and strategic marketing, question.

\section{Figure 6}

A conceptual framework of the relationship between MI quality and strategic marketing

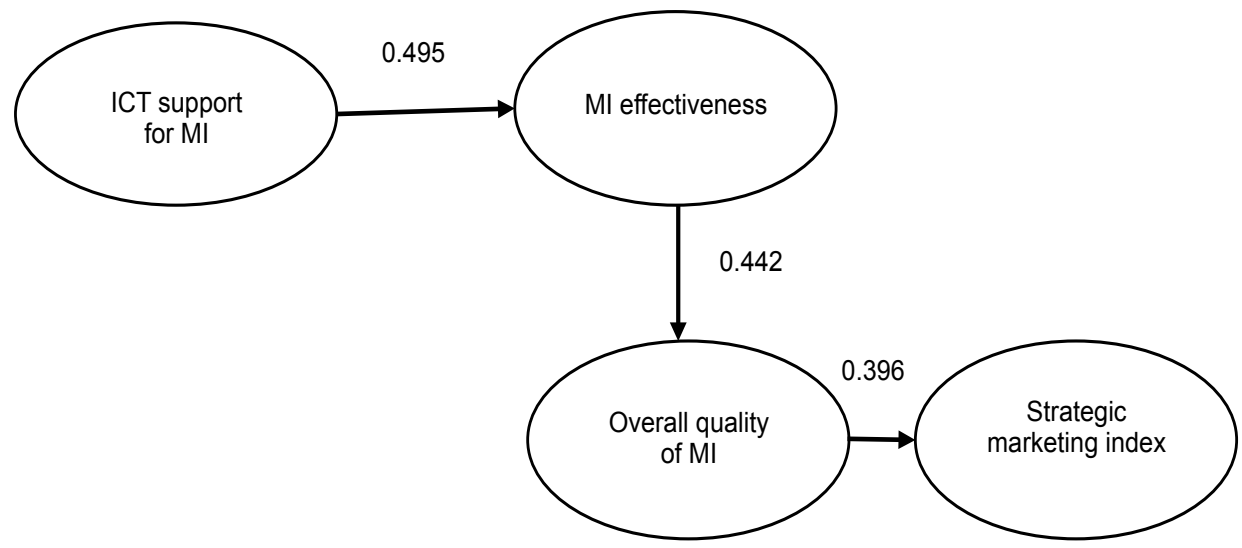

The study found that the MI Effectiveness construct has a strong relationship with the overall perception of quality of MI. ICT
Support, in turn, had a strong relationship with the MI Effectiveness construct, suggesting a moderating role for MI Effectiveness as a 
variable. However, further analysis of the results suggest that the relationship between ICT and MI is a weak area for many organisations, and it is recommended that organisations should invest in better alignment of ICT systems and marketing decision-maker needs.

In summary the findings suggest a strong relationship between the perception of overall quality of $\mathrm{MI}$ and the strategic marketing index. The perception of MI quality is, in turn, influenced by MI Effectiveness and the availability of market intelligence. The key drivers of MI Effectiveness are ICT Support and the use of MI tools and technologies, while the availability of market intelligence is strongly related to the availability of other categories of MI. The conceptual framework is depicted in Figure 7.

\section{Figure 7}

A conceptual framework of the relationship between $\mathrm{Ml}$ and strategic marketing

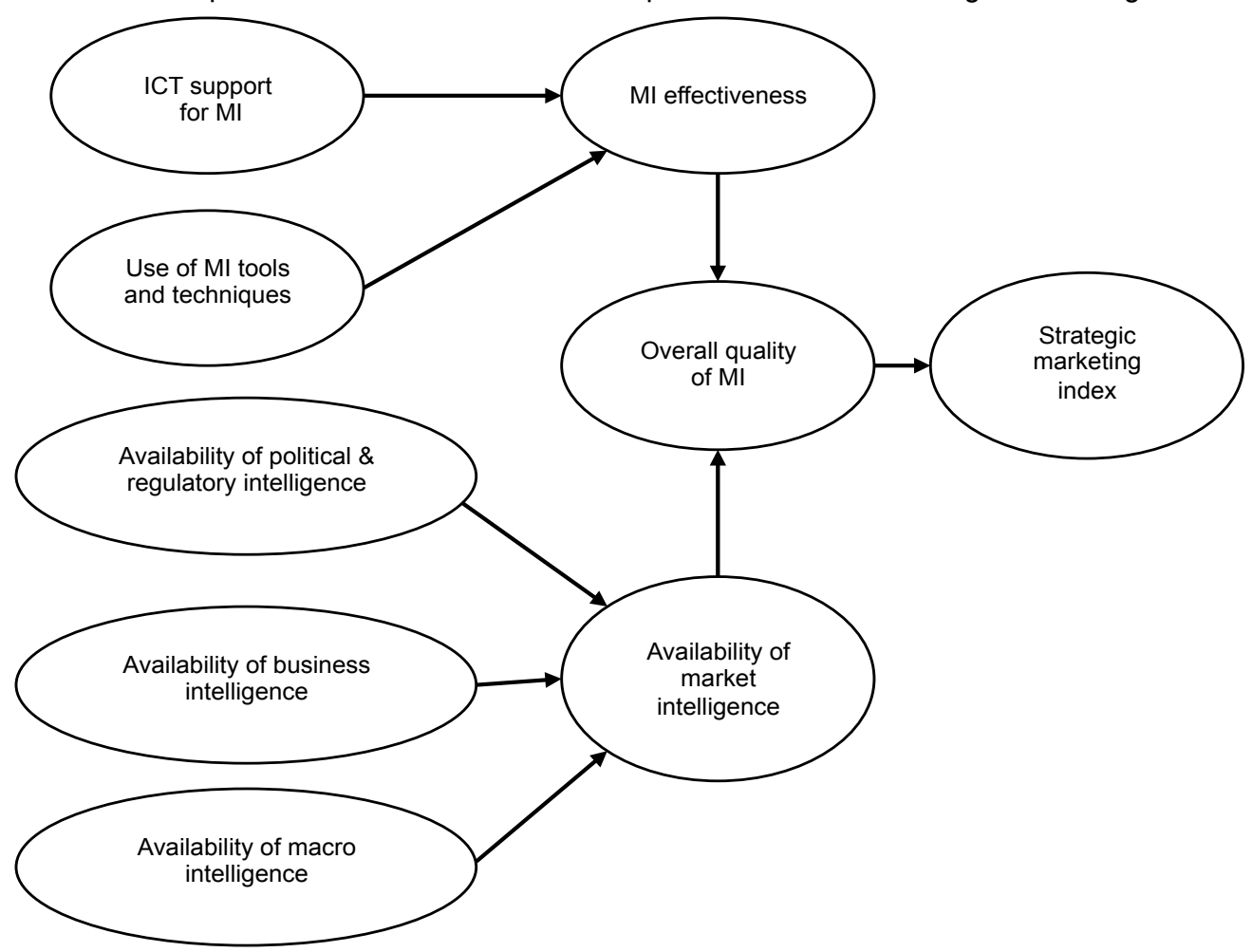

The study suggests a number of areas for future research. First, the conceptual model will benefit from future research and modelling (for example structured equation modelling) to confirm and expand the findings of this study beyond correlational research. Second, the relationship between MI and strategic marketing is an area that remains relatively unexplored and would benefit from more research in different contexts, such as specific industries and other geographical areas. Third, the relationship between ICT and MI, while it is recognised as important, is relatively unexplored and would benefit from further research to understand how ICT could better support MI and ultimately strategic marketing. Fourth, the relationship between MI and specific elements of strategic marketing (such as market segmentation) would add depth to our understanding of the relationship between MI and strategic marketing. Finally, while quantitative research is useful in better understanding the generalities of MI and its relationship with strategic marketing, more qualitative research is required to expand our understanding of how the relationship between MI and strategic marketing unfolds in practice. 


\section{Acknowledgements}

The authors thank two anonymous reviewers for their extensive and useful comments.

\section{References}

ALDAS-MANZANO, J., KÜSTER, I. \& VILA, N. 2005. Market orientation and innovation: an interrelationship analysis. European Journal of Innovation Management, 8(4):437-452.

BERNSTEIN, P.A. \& HAAS, L.M. 2008. Information integration in the enterprise. Communications of the $A C M$, 51(9):72-79.

BEST, R.J. 2009. Market-based management: strategies for growing customer value and profitability (5th ed.) New Jersey: Pearson Prentice Hall.

BRIEN, R. \& STAFFORD, J. 1969. Marketing information systems: a new dimension for marketing research. Journal of Marketing, 32(3):19-23.

COHEN, J. 1988. Statistical power analysis for the behavioral sciences (2nd ed.) New Jersey: Lawrence Erlbaum Associates.

CONRADIE, P.J. \& KRUGER, P.S. 2006. The necessity of information quality for effective business intelligence. SA Journal of Industrial Engineering, 17(1):129-147.

COUPER, M.P. 2005. Technology trends in survey data collection. Social Science Computer Review, 23(4):486-501.

CRAVENS, D.W. \& PIERCY, N. 2006. Strategic marketing (8th ed.) New York: McGraw-Hill.

DANIEL, E., WILSON, H. \& McDONALD, M. 2003. Towards a map of marketing information systems: An inductive study. European Journal of Marketing, 37(5/6):821-847.

DIBB, S., SIMKIN, L, PRIDE, W.M. \& FERRELL, O.C. 2012. Marketing: Concepts and Strategies (6 ${ }^{\text {th }}$ ed.) Hampshire: CENGAGE Learning.

ELLIS, P.D. 2005 Market orientation and marketing practice in a developing economy. European Journal of Marketing, 39(5/6):629-645.

FORLANI, D. \& PARTHASARATHY, M. 2003. Dynamic market definition: an international marketing perspective. International Marketing Review, 20(2):142-160.

GORETSKY, M.E. 1983. Frameworks of strategic marketing information needs. Industrial Marketing Management, 12(1):7-11.

HAIR, J.F., BLACK, B., BABIN, B., ANDERSON, R.E. \& TATHAM, R.L. 2005. Multivariate Data Analysis (6th ed.) New Jersey: Pearson Prentice Hall.

HUSTER, M. 2005. Marketing intelligence: a first mover advantage. Competitive Intelligence Magazine, $8(2): 13-17$

JAWORSKI, B.J. \& KOHLI, A.K. 1993. Market orientation: antecedents and consequences. Journal of Marketing, 57 (July):53-70.

KARA, A., SPILLAN, J.E. \& DESHIELDS, O.W. jr. 2005. The effect of a marketing orientation on business performance: a study of small-sized service retailers using MARKOR scale. Journal of Small Business Management, 43(2):105-118.

KELLEY, W.T. 1965. Marketing intelligence for top management. Journal of Marketing, 29(4):19-24.

KENT, R. 2001. Data construction and data analysis for survey research. New York: Palgrave.

KING, W.R. \& CLELAND, D. 1974. Environmental systems for strategic marketing planning. Journal of Marketing, 38(4):35-40

LACKMAN, C., SABAN, K. \& LANASA, J. 2000. The contribution of market intelligence to tactical and strategic business decisions. Marketing Intelligence and Planning, 18(1):6-8.

LOUW, L. \& VENTER, P. 2010. Strategic management: Developing sustainability in Southern Africa (2nd ed.) Cape Town: Oxford University Press.

MARKETING SCIENCE INSTITUTE, 2010. Research priorities 2010-2012. Available at: http://www.msi. org/pdf/MSI RP10-12.pdf [accessed 12 February 2011].

McDONALD, M. \& DUNBAR, I. 2004. Market segmentation: how to do it, how to profit from it. Burlington: Elsevier Butterworth-Heinemann. 
MOCKLER, R.J. 1992. Strategic intelligence systems: Competitive intelligence systems to support strategic management decision-making. S.A.M. Advanced Management Journal, 57(1):4-10.

MONTGOMERY, D.B. \& WEINBERG, C.B. 1998. Towards strategic intelligence systems. Marketing Management, 6(4):44-52.

MORGAN, N.A., VORHIES, D.W. \& MASON, C.H. 2009. Market orientation, marketing capabilities, and firm performance. Strategic Management Journal, 30(8):909-920.

ROTHSCHILD, W.E. 1979. Comment on the need for a strategic intelligence system. Journal of Marketing, 43(4):53-54.

SARVARY, M. \& ELBERSE, A. 2006. Market segmentation, target market selection, and positioning. Harvard Business School Module Note, HBA No. 9-506-019:1-5.

SHOHAM, A., ROSE, G.M. \& KROPP, F. 2005. Market orientation and performance: A meta-analysis. Marketing Intelligence \& Planning, 23(4/5):435-454.

TAGHIAN, M. \& SHAW, R.N. 2010. Market fit and business performance: An empirical investigation. Journal of Strategic Marketing, 18(5):395-415.

TAN, T.W. \& AHMED, Z.U. 1999. Managing market intelligence: an Asian marketing research perspective. Marketing Intelligence \& Planning, 17(6):298-306.

TAYLOR, M. D. 1936. Progress in marketing research. Journal of Marketing, 1(1):56-64.

TONKS, D.G. 2009. Validity and the design of market segments. Journal of Marketing Management, 25 (3-4):341-356.

TRIM, P.R.J. 2004. The strategic corporate intelligence and transformation model. Marketing Intelligence \& Planning, 22(2/3):240-256.

TRIM P.R.J. \& LEE, Y. 2008. A strategic marketing intelligence and multi-organizational resilience framework. European Journal of Marketing, 42(7/8):731-745.

VENTER, P. \& JANSEN VAN RENSBURG, M. 2009. Strategic marketing: Theory and application for competitive advantage. Cape Town: Oxford University Press.

VENTER, P. \& TUSTIN, D. 2009. The availability and use of competitive and business intelligence in South African business organisations. Southern African Business Review, 13(2):88-117.

VELICER, W.F. \& FAVA, J.L. 1998. Effects of variable and subject sampling on factor pattern recovery. Psychological Methods, 3(2):231-251.

WEE, T.T.T. 2001. The use of marketing research and intelligence in strategic planning: Key issues and future trends. Marketing Intelligence and Planning, 19(4):245-253.

WALKER, O.C., MULLINS, J.W. \& LARRÉCHÉ, J. 2008. Marketing strategy (6th ed.) Singapore: McGraw-Hill. 